\title{
Sideswipes and Backhanders: Abolition of the Reasonable Chastisement Defence in South Africa
}

\author{
Julia Sloth-Nielsen* \\ ${ }^{*}$ Public Law and Jurisprudence, University of the Western Cape, South Africa; University of Leiden, The Netherlands.
}

ABSTRACT

This article reviews the abolition of the defence of reasonable chastisement by the South African Constitutional Court on the grounds that it infringes the Constitution. After detailing the history of the abolition of corporal punishment in a democracy with the Constitution as supreme law, the article dissects the reasoning of the Constitutional Court. It argues that judgment in Freedom of Religion South Africa $v$ Minister of Justice and Constitutional Development (hereafter FORSA), whilst overall positive in its result, is probably a low water mark in the development of children's rights jurisprudence in South Africa. There are a number of inadequacies and strangely deferential statements in the FORSA decision. Whilst inescapably coming to the constitutionally correct decision, the reluctance of the Court to reach this point, and its desire to accommodate the religious and cultural beliefs of the appellants, is evident. The way forward has, as a result, been left rather obscure.

\section{INTRODUCTION}

This article reviews the abolition of the defence of reasonable chastisement by the South African Constitutional Court on the grounds that it infringes the Constitution. After detailing the history of the abolition of corporal punishment in a democracy with the Constitution as supreme law, the article dissects the reasoning of the Constitutional Court. It also reviews what the Court did not do. It attempts to map out what the Court expects to ensue next, and what legislative steps are potentially in the offing. It argues that judgment in Freedom of Religion South Africa $v$ Minister of Justice and Constitutional Development ${ }^{1}$ (hereafter FORSA), whilst overall positive in its result, is probably a low water mark in the development of children's rights jurisprudence in South Africa; that the opportunity to educate Joe and Jane Public on the reasons for the judgment was largely missed; and that the way forward has been left rather obscure. 
Prior to 1994, when the first (interim) constitution was adopted, corporal punishment had a deeply colonial, racist, and politicised character. ${ }^{2}$ As elaborated in detail by Pete, lashings to the body were a feature of slavery in South Africa (as elsewhere), which permitted the harsh physical discipline of slaves by their masters. Master and servant laws entrenched this even after the abolition of slavery. In the criminal justice system, South Africa adopted the physical punishments of Europe, such as lashings, drawing and quartering, hanging, and sentences to walk the treadmill. Whipping continued as a competent sentence throughout most of the 20th century. ${ }^{3}$

The introduction of harsher sentences for political dissidents was a phenomenon noted as resistance to apartheid increased. ${ }^{4}$ Even at the dawn of democracy, whipping remained a competent sentence for certain criminal offences. It was, until 1994, the favoured punishment for juvenile offenders. ${ }^{5}$

$S v$ Williams $^{6}$ marked a turning point. The facts have been well described ${ }^{7}$ : a magistrate imposed a series of sentences of whipping upon young offenders in his jurisdiction, and then suspended imposition of these sentences pending a constitutional review of their validity. In one of the first postconstitution judgments the Constitutional Court ruled that judicial corporal punishment was an infringement of the right to freedom and security of the person. Its abolition was, according to the Court, to serve as a timely reminder to the State to develop a child justice system based on human rights. ${ }^{8}$

The Williams case was followed by the case confirming the constitutionality of a legislative ban on corporal punishment in schools. In Christian Education South Africa $v$ Minister of Education, ${ }^{9}$ the Constitutional Court found that the prohibition on corporal punishment was a reasonable and justifiable limitation of parental rights to freedom of religion. Moreover, the failure to provide an exemption from the general rule to accommodate the applicant parent group's religious views was also held to be reasonable and justifiable. The judgment turned, amongst others, on the fact that that punishment was applied in the school setting, which was a 'detached and institutional environment', 10 and not in 'the intimate and spontaneous atmosphere of the home'. ${ }^{11}$ The Court stressed the need to diminish the amount of public and private ${ }^{12}$ violence in society, ${ }^{13}$ and to protect children from

2 S. Peté, 'Punishment and Race: The Emergence of Racially Defined Punishment in Colonial Natal' (1986) 1 (2) Natal University Law and Society Review 99-114.

3 Ibid.

4 A. Roberts and J. Sloth-Nielsen, 'Whippings, the Courts, the Legislature and the Unrest' (1986) 2 SAJHR 224-29; D. van Zyl Smit and L. Offen, 'Corporal Punishment: Joining Issue' (1984) 8 South African Journal of Criminal Law and Criminology 69.

5 J. Sloth-Nielsen, 'Corporal Punishment: Acceptable State Violence?' in D. van Zyl Smit and D. Hansson (ed.), Towards Justice: Crime and State Control in South Africa (1990) Oxford University Press, Johannesburg.

61995 (3) SA 632 (CC).

7 See A. Skelton, 'S v Williams: A Springboard for Further Debates about Corporal Punishment' (2016) Acta Juridica 336, 338-39.

8 Williams (n 6) para 74.

92000 (4) SA 757 (CC).

10 Ibid, para 49.

11 Ibid, para 49.

12 Ibid, para 48.

13 Ibid, para 48. 
maltreatment, abuse, or degradation. ${ }^{14}$ The Court expressly stated that the issue as to the constitutionality of corporal punishment in the home was not before it for consideration.

\section{THE BACKGROUND TO FORSA V MINISTER OF JUSTICE}

Previous endeavours to restrict or remove the common law defence of reasonable chastisement in South Africa were not successful. During the development of the Children's Act 38 of 2005, the South African Law Reform Commission placed the issue on the table, proposing the removal of the defence of reasonable chastisement available to parents ${ }^{15}$; this 'pared down' proposal was further developed and a much more elaborate version presented to Parliament. ${ }^{16}$ Parliament, however, refused to countenance legislative intervention. ${ }^{17}$ So vehement was the Parliamentarians' support for parental corporal punishment that it was threatened that the entire Children's Bill would be taken off the table if the Department of Social Development did not take out the offending provisions on corporal punishment. The Parliamentarians' opposition was based on their personal preference for corporal punishment as a method of discipline. ${ }^{18}$

Civil society organisations had for some years thereafter debated the efficacy of mounting a constitutional challenge, but the experiences of foreign jurisdictions, such as Canada, ${ }^{19}$ where a setback cast the continued existence of the defence in stone for decades to come, served as a significant deterrent. Also, a change in the composition of the Constitutional Court bench weighed against a legal challenge. ${ }^{20}$

The impetus for FORSA originated in a criminal prosecution of $Y G$ for assault. Initially charged with the more severe charge of assault with intent to do grievous bodily harm on both his wife and teenage son, the accused was convicted of what, on the facts, was found to be quite a serious assault causing severe bruising, kicking, and

14 Ibid, para 41.

15 South African Law Reform Commission Report on the Review of the Child Care Act (Project 110) (2002) 120, 121.

16 Children's Bill B 19 of 2006.

17 This occurred when the principal Children's Act 38 of 2005 was debated as well as subsequently, during the consideration of the Regulations. The Act and regulations were debated separately on two separate occasions in Parliament, and on both occasions attempts to legislative restrict the parental reasonable chastisement defence were vigously opposed by Parliamentarians. This is in the personal knowledge of the author who was the lead drafter of the regulations. See further Skelton (n 7); J. Sloth-Nielsen, 'Southern African Perspectives on Banning Corporal Punishment - A Comparison of Namibia, Botswana, Zimbabwe and South Africa' in B. Saunders, P. Leviner, and B. Naylor (eds.), Corporal Punishment of Children (Brill/Nijhoff Publishers, The Netherlands, 2019).

18 The author was present in person during these Parliamentary debates.

19 Aspects of the Canadian position are discussed in more detail below at Section III.4.

20 A. Skelton, 'Children's Rights' in Brickhill J (ed) Public Interest Litigation in South Africa (Juta, Juta Cape Town, 2018) notes as follows at p. 273:

The [strategic litigation] plans were quite advanced-a legal opinion had been drafted, an expert opinion had been commissioned, and an individual as well as institutional client had been found. At the crucial moment, however, there was a major change at the Constitutional Court, with four experienced justices leaving the court at the same time. At least three of these were known to be 'child rights sympathetic' judges. Their sudden absence, and the uncertainty about who would replace them, caused the legal team to pull back from filing the application. 
shoving the boy against a door. The violence was reportedly inflicted because the father suspected that his son had been watching pornography and had lied about it. The level of violence used in the first assault was in contention. On appeal from the initial criminal court, the Appellant (YG) argued that he had used his open palms to punish his son, but a testimony by a medical doctor indicated that the bruising in question was inflicted by the use of a fist rather than by open palms.

Although faced with a fully suspended sentence, YG appealed his conviction to the High Court. ${ }^{21} \mathrm{He}$ relied on the reasonable chastisement defence, as well as the constitutional right to freedom of religion, as grounds for seeking to overturn the conviction. As a devout Muslim, he argued that he was exercising his right to religious freedom, as he averred that physical punishment was sanctioned by the applicable religious texts pertinent to his religion.

At the High Court level, the judge of her own accord raised the question as to whether the reasonable chastisement defence could pass constitutional muster. She invited the Centre for Child Law, a public interest strategic litigation centre, and FORSA, an organisation representing various (Christian) religions in South Africa, to enter as amici curiae and to present arguments to the Court.

The learned judge noted the array of constitutional rights at stake: these include the

right to human dignity (section 10); the right to equal protection under the law (section 9(3); the right to be free from all forms of violence from either public or private sources (section $12(1)(\mathrm{c})$ ); the right not be treated or punished in a cruel, inhuman or degrading way (section $12(1)(\mathrm{e})$ ); the right of children to be protected from maltreatment, neglect, abuse or degradation (section 28(1)(d)); and the constitutional principle that a child's best interests are of paramount importance in every matter concerning the child (section $28(2))^{22}$

The judge elaborated why the reasonable chastisement defence could not survive constitutional scrutiny. Recalling that the courts have a duty to develop the common law to bring it in line with the Constitution, ${ }^{23}$ the Court felt that it was in the interests of justice to determine whether the common law defence passed constitutional muster, even if such a finding was to have only prospective application. Noting that the defence was rooted in the Western conception of the law's respect for parents in fulfilling their child-rearing responsibilities, including disciplining their children, the Court noted that the exception to an assault charge was only available when the punishment meted out was for bona fide disciplinary purposes and was reasonable or moderate, ie not excessive. ${ }^{24}$ In determining what is reasonable or moderate, courts

21 YG v S 2018 (1) SACR 64 (GP). Reportedly, the suspended sentences were accompanied by his being disqualified from owning a firearm, which was the main reason for his initial appeal against the conviction of the lower court. 
may in the past have taken a variety of factors into account, such as the degree of force, the object used, and the age, sex, and build of the child.

After listing the various constitutional rights implicated in the inquiry (dignity, freedom from all forms of violence from either public or private sources, protection of the child from maltreatment, abuse and degradation, and so forth), the Court conceded that the family was a critical component of the constitutional inquiry in the weighing and balancing of interests, even if the Constitution does not provide directly for a right to family life. ${ }^{25}$ Notwithstanding, the judgment gave primacy to children's rights, evidenced in the citations drawn from $S v M$ (Centre for Child Law Intervening $)^{26}$ according to children an independent right to dignity, and their right to grow up in a situation 'free from violence, fear, want and avoidable trauma'. ${ }^{27}$ Citing an array of international documents as well as domestic legislation, ${ }^{28}$ the Court found that the common law defence was premised on outdated notions of parental authority or power, which were now at odds with a children's rights approach. ${ }^{29}$ Moreover, the common law defence did not set clear boundaries as to what would be permissible, meaning that it entailed a measure of arbitrariness, as what would be considered reasonable was context and child-victim dependent. It would then be up to parents to determine reasonableness, in the circumstances. ${ }^{30}$ The Constitutional prohibition in section $12(1)$ (c) extends to a prohibition of violence from all sources, including from parents. ${ }^{31}$ Further, conduct that but for the existence of the reasonable chastisement defence would constitute assault, breaches the child's (independent) right to dignity, which is a foundational constitutional value. ${ }^{32}$ The defence also does not give children equal protection under the law, as they are in a different situation to adults who are protected from the application of force, without there being grounds for a rational distinction to be drawn between adults and children. ${ }^{33}$ The defence also undermines the duty of the state to protect children from violence and degradation and to protect their best interests. ${ }^{34}$ The Court could find no justification for limiting the rights transgressed by the continued operation of the defence.

The Appellant (YG) did not pursue the matter further than this. However, unusually, FORSA, which had been invited as an amicus in the appeal, approached the Constitutional Court to have the finding overturned. The Centre for Child Law, representing Sonke Gender Justice, the Quaker Peace Centre, and the Children's Institute, opposed the merits of the application in the interests of obtaining legal certainty and a decision of national application (and one that was not just binding in Gauteng province, where the initial finding of constitutional invalidity was made).

25 Ibid, para 38.

262008 (3) SA 232 (CC).

27 YG v $S$ (n 21) para 46.

28 For a more in depth discussion of this aspect, see B. Mezmur, 'Don't Try This at Home: Reasonable or Moderate Chastisement, and the Rights of the Child in South Africa with YG v S in Perspective' (2018) 32 (2) Speculum Juris 75-92.

$29 Y G v S(\mathrm{n} \mathrm{21})$ paras 62 and 64.

30 Ibid, para 68.

31 Ibid, para 69.

32 Ibid, para 73.

33 Ibid, para 75.

34 Ibid, para 76. 
The judgment of the Constitutional Court saw the light of day just short of a year after arguments were heard.

\section{THE REASONING OF THE CONSTITUTIONAL COURT}

In a unanimous decision, the Constitutional Court (per Mogoeng CJ) ruled that the common law defence of reasonable chastisement could not pass constitutional scrutiny. In effect, the decision has been regarded as outlawing parental corporal punishment, as parents (if charged with any form of assault) cannot raise their right to discipline their children as a way of avoiding their actions being characterised as unlawful. In this section of the article, aspects of the format and reasoning of the judgment are dissected, and some worrying features highlighted.

\section{Limitation of the Issues}

At the outset, the judgment limits the grounds that it would consider. The main reasons advanced for this are the need to avoid 'wasting words' on issues that, whilst relevant, do not add significantly to the outcome. ${ }^{35}$ The result is, in the view of the author, a remarkably short judgment (given the huge importance of the issues, the volume of submitted arguments, and the public interest): stripped of the opening page, the closing page listing the legal participants, and the decision on legal standing (since the appellant in the Constitutional Court was an amicus in the court a quo rather than being a party, and since direct access had been applied for), the reasoning is barely 26 pages long.

Moreover, the children's rights dimensions of the judgment are somewhat underwhelming. The child's best interests are adduced - but really situated in the context of whether children of tender age can pursue remedies for violations of their rights if parents or caregivers overstep the bounds of reasonable chastisement. ${ }^{36}$ This is supplemented by a reference to the best interests of older children, who might not know how to pursue any action to stop abuse. ${ }^{37}$ The judgment does mention the 'duty to respect promote and fulfil a child's section 28 protections, ${ }^{38}$ but confusingly continues that in our approach to a parent's entitlement to chastise a child reasonably and moderately, of paramount importance should be the best interests of the child in respect of protection from potential abuse and the need to limit the right because of the good a child and society stand to derive from its retention as a disciplinary tool'. ${ }^{39}$ What good do the child and society stand to derive from the retention of corporal punishment as a disciplinary tool? And how is this to square with the best interests principle? This is not self-evident.

The best interests principle played an overarching role in Christian Schools, where Judge Sachs spoke of the overall interests of children in growing up in a less violent society. The paramountcy of the best interests principle from a

35 Ibid, para 30: '[v] ery little purpose is hardly ever served by the long-windedness that takes the form of trolling down all the rights, principles or issues implicated or raised in order to arrive at the same conclusion.'

36 Ibid, para 55.

37 Ibid, para 55.

38 Ibid, para 56.

39 Ibid, para 56. 
constitutional and children's rights vantage point ${ }^{40}$ dictates that the preferable route in FORSA would have been to adopt a more expansive understanding of the operation of the best interests in the context of the abolition of the reasonable chastisement defence, ${ }^{41}$ as this could assist ordinary citizens to better understand why the continued existence of the defence could not stand scrutiny. So, for instance, one of FORSA's claims was that removal or restriction of the defence was antithetical to children's best interests, ${ }^{42}$ because it is indeed in children's best interests to be disciplined by their parents. But a more generalised discussion would have seen the Court articulate that children, who are a more vulnerable group deserving of special protection (and whose best interests are of paramount importance in the Constitutional scheme) should not be granted less protection than adults in respect of whom a reasonable chastisement defence does not apply when violence is perpetrated. ${ }^{43}$

The child's (constitutional) right to protection from abuse, neglect, maltreatment, and degradation ${ }^{44}$ is not mentioned at all in the judgment. ${ }^{45}$ This is quite startling, given the levels of violence in South Africa. In the most recent study on violence prevalence in South Africa, ${ }^{46}$ the first ever national evidence-based study on the incidence of violence upon children in South Africa, for which 10,000 participants aged 15-17 were polled, it was found that one in three children experience sexual violence or physical abuse before the age of 18 . Twelve per cent of children report neglect, and 16 per cent emotional abuse. The 2013-2014 police crime statistics indicate that 29 per cent of cases of sexual abuse (18,524 cases) concerned victims who were under 18. This equates to 51 cases per day. Statistics released by UNICEF in 2018 are equally disturbing in revealing the levels of violence against children in South Africa. ${ }^{47}$

There is no quibble with the primary rights relied upon in the judgment: the constitutionality of moderate and reasonable chastisement was to be primarily be resolved on the provision of section $12(1)(c)^{48}$ of the Constitution, while the right

40 See further for an in depth discussion of the role of the best interests of the child and their relationship with other constitutional rights, A, Skelton, 'Chapter 11: Constitutional protection of Children's Rights' in T Boezaart (ed.), Child Law in South Africa (Juta, Cape Town, 2017).

41 The CRC Committee in General Comment No 13 has outlined the three aspects of 'best interests': namely a 'substantive right'; a 'fundamental, interpretative legal principle'; and 'a rule of procedure', in assessing and determining the best interests of the child.

42 Mezmur (n 28) 79.

43 FORSA (n 1) para 72.

$44 \mathrm{~s} 28(1)(\mathrm{d})$.

45 Skelton (n 7) accords particular weight to the importance of 'degrading treatment' in her analysis, noting that South African jurisprudence (before FORSA) 'appears to favour the idea that corporal punishment is degrading' (p. 353).

46 Centre for Justice and Crime Prevention and Gender Health and Justice Research Unit, University of Cape Town, 'The Optimus Study on Child Abuse, Violence and Neglect in South Africa' (2015) www. optimusstudy.org.

47 UNICEF Annual Report 2018, https://www.unicef.org/southafrica/SAF_resources_annual2017.pdf (accessed December 2019).

48 '(1) Everyone has the right to freedom and security of the person, which includes the right-

(c) to be free from all forms of violence from either public or private sources.' 
to dignity also receives attention in the discussion. ${ }^{49}$ Nevertheless, neglect of the consideration and elaboration of the child's right to protection from abuse, neglect, degradation, and maltreatment arguably weakens the judgment and creates room for some of the gaps which are discussed next. ${ }^{50}$

\section{Language}

The Court uses fairly consistent language to describe the mischief, the constitutionality of which was in issue. Nowhere is there any reference to smacking, corporal punishment in the home, or physical punishment. The terminology is that of 'chastisement', 51 which is defined as including a verbal reprimand, a rebuke, or severe criticism. ${ }^{52}$ It is a rather sanitised (and old fashioned) word, in reality. At the same time, the vocabulary is justified by the wording of the common law defence itself, as well as the language used by the appellants (they characterised their claim for continuation of the defence as being premised on 'parental entitlement to lovingly discipline their child'). ${ }^{53}$ But, with respect, was the terminology not overly deferential to the sincerely held beliefs of the applicants?

World-famous anti-corporal punishment campaigner, Joan Durrant, talks more bluntly of 'corrective assault'. ${ }^{54}$ The South African judgment does correctly refer to a broad reading of the word 'violence' in section $12(1)(\mathrm{c})$, meaning that it extends to all forms of chastisement, 'moderate or extreme - a smack or a rod'. ${ }^{55}$ This accords well with jurisprudence from the Committee on the Rights of the Child. In General Comment $8,{ }^{56}$ the Committee on the Rights of the Child took a major step forward by erasing the distinction between 'minor' and 'severe' punitive violence.

The Committee defines 'corporal' or 'physical' punishment as any punishment in which physical force is used and intended to cause some degree of pain or discomfort, however light. Most involves hitting ('smacking', 'slapping', 'spanking') children, with the hand or with an implement - a whip, stick, belt, shoe, wooden spoon, etc. But it can also involve, for example, kicking, shaking or throwing children, scratching, pinching, biting, pulling hair or boxing ears, forcing children to stay in uncomfortable positions, burning, scalding or forced ingestion (for example, washing children's mouths out with soap or forcing them

49 FORSA (n 1) para 31.

50 J. Durrant, A. Stewart-Tufescub, and T. Afifi, 'Recognizing the Child's Right to Protection from Physical Violence: An Update on Progress and a Call to Action' (2019) Child Abuse and Neglect, DOI: 10.1016/ j.chiabu.2019.104297.

51 For example, FORSA (n 1) paras 29, 31, and 32.

52 Dictionary.com (accessed 9 December 2019); although a second leg given as part of the definition on this source is corporal punishment. The Cambridge law dictionary also commences the definition of chastise with 'to criticize someone severely', and to punish someone, especially by hitting them.

53 FORSA (n 1) para 33.

54 It is interesting that the term corrective rape/assault does get used when describing attacks on LGBTQI people.

55 FORSA (n 1) para 40.

$56 \mathrm{CRC} / \mathrm{C} / \mathrm{GC} / 8$ (2006). See also Committee on the Rights of the Child General Comment No 13 on Violence against Children $\mathrm{CRC} / \mathrm{C} / \mathrm{GC} / 13$. 
to swallow hot spices). In the view of the Committee, corporal punishment is invariably degrading. ${ }^{57}$

Thus, the Committee established that there are no lines to be drawn based on whether the adult hits with a hand or with an object, the age of a child who is shaken, the parts of the body struck, or the adult's intent to teach versus injure the child. From the child's perspective, all are acts of violence. Therefore, the Committee removed the arbitrary line between 'abusive' and 'non-abusive' punitive violence. There is no ambiguity: 'All forms of physical or mental violence' does not leave room for any level of legalised violence against children. Corporal punishment and other cruel or degrading forms of punishment are forms of violence and states must take all appropriate legislative, administrative, social, and educational measures to eliminate them. ${ }^{58}$ The General Comment is, however, not referred to in the FORSA judgment. $^{59}$

\section{The 'Natural Habitat' of Criminal Law}

Adopting the view that the reasonable chastisement defence belongs in the 'natural habitat' of the criminal law, ${ }^{60}$ the Court in essence does not actually rule out corporal punishment in the home - as advocacy groups and the layman (even the specialist) would read the decision. ${ }^{61}$ Plainly put, the judgment has the consequence that was a parent or caregiver to be criminally charged with assault or any other offence involving offending bodily integrity, the reasonable chastisement defence would not be available. This is arguably a step once removed from curtailing (undetected) parental physical punishment. It more narrowly seems to restrict the scope of the ruling to the reach of criminal law.

This fine distinction was uppermost in the minds of the South African Law Reform Commission when it debated what to legislate in connection with parental corporal punishment in the preparatory work on the Children's Act 37 of 2005. The Commission discussed various proposals, ranging from removal of the reasonable chastisement defence, to provide much more directly for criminal sanctions for the imposition of physical punishment upon children by their parents. ${ }^{62}$ It was

$57 \quad$ Para 11.

58 General Comment No 8, para 18.

59 In the past, the Constitutional Court has paid considerable attention to the Convention on the Rights of the Child and has in some instance relied on the Committee's General Comments. See R. Ngidi, 'The Role of International Law in the Development of Children's Rights in South Africa: A Children's Rights Litigator's Perspective' in M. Killander (ed.), International Law and Domestic Human Rights Litigation in Africa (PULP- Pretoria University Law Press, Pretoria) (2010) 173-91.

60 FORSA (n 1) para 37.

61 See for instance www.endcorporalpunishment.com and the newsletter produced on a regular basis by this organisation.

62 South African Law Reform Commission Report on the Review of the Child Care Act 74 of 1983 (Project 110) (2002):

On the one hand, the Commission recommended the adoption of an educative and awarenessraising approach in respect of corporal punishment. The aim of such an approach would be to educate parents and care-givers about the harmful effects of corporal punishment and to empower such parents or care-givers to use successfully alternative forms of discipline in the home. To support this educative approach, the Commission also adopts a criminal law approach which 
thought that removal of the reasonable chastisement defence would be the more politically palatable option ${ }^{63}$; it would be simpler and easier to 'sell' publicly than an elaborate provision providing criminal sanctions for parents; ultimately, though, all references to corporal punishment were removed at the insistence of Parliament, as mentioned. ${ }^{64}$

The Court explained the definition of 'all forms of violence', noting its reach to extends 'behaviour involving physical force intended to hurt, damage or kill someone or something. 65 'Violence is not so much about the manner and extent of the application of the force as it is about the mere exertion of some force or the threat thereof.' The Court cites as examples of assault the situation where a man touches a woman on her breast or behind without permission or deliberately bumps that against those parts of her body, in which situation our courts have held that this conduct would amount to assault. ${ }^{66}$ The Court was emphatic that the constitutional protection extends to violence from privates sources, which necessarily implicates corporal punishment in the home setting.

In the face of the above, FORSA's depiction of the reasonable chastisement defence as having its natural home in the realm of criminal law tends to suggest that, the extension of the protection of section $12(1)(\mathrm{c})$ to the private sphere notwithstanding, it will only play out when a criminal charge is laid or prosecution instituted. This must surely leave the public (and law enforcement and social welfare authorities) very confused about the full extent of the implications of the decision.

\section{De Minimis Non Curat Lex}

The reach (or limits?) of the decision, as explained immediately above, is reinforced by the references to de minimis non curat lex: the law does not concern itself with trifles. ${ }^{67}$ However, the court does not - correctly in my view - define what this could entail in the context of physical punishment. To define what is 'trivial' in the context of physical punishment could be the reverse side of the coin of what occurred in the

will in effect facilitate the possibility of prosecuting parents in the criminal courts on charges of assault or assault with the intent to cause grievous bodily harm for inflicting corporal punishment upon a child. To facilitate the criminal prosecution, the Commission recommended the repeal of the common-law defence that a parent may raise that the physical punishment was justified on the grounds of the rights of parents to impose reasonable chastisement upon their children. (para 9.7 at p. 115)

and

Rather than to advocate for an outright ban, the Commission recommends, as it did in the discussion paper, that the common law defence of reasonable chastisement available to a parent facing a charge of assault or assault with the intention to cause grievous bodily harm be revoked and that an educational and awareness programme be developed to equip parents with alternative forms of discipline. (para 9.7 at p. 121)

63 The author was a member of the Project Committee which was undertaking this endeavour.

64 This is more fully described in J. Sloth-Nielsen, 'Southern African Perspectives on Banning Corporal Punishment - A Comparison of Namibia, Botswana, South Africa and Zimbabwe' in B. J. Saunders, B. Naylor, and P. Leviner (eds.), Comparative Social and Legal Developments in Dealing with Corporal Punishment of Children (Brill publishers, The Netherlands, 2018).

65 FORSA (n 1) para 38.

66 Ibid, para 35 and footnotes, citing $R v M$ (1961) 2 SA 60 (O).

67 The applicability of this principle to the topic at hand is referred to in paras 35 and 52. 
infamous Canadian judgment in Canadian Foundation for Children, Youth and the Law v Attorney General Canada. ${ }^{6}$ To recall, the Canadian Supreme Court declined to rule the defence of reasonable chastisement ${ }^{69}$ as being in violation of the Canadian Constitution in 2004. The Court determined, controversially, that the boundaries of 'reasonable and moderate' chastisement could indeed be fashioned. These boundaries included that chastisement could only be administered by a parent, that the child is aged between 2 and 12 years (inclusive), that the child is capable of learning from it, ${ }^{70}$ that it involves a minor corrective force of a transitory and trifling nature, ${ }^{71}$ that it does not involve the use of objects, or blows or slaps to the head, that it is corrective, not the result of the parent's 'frustration, loss of temper or abusive personality', and that it is not degrading, inhuman or harmful. However, Durrant et $\mathrm{al}^{72}$ have found, in their examination of child protection cases, that the criteria set by the Canadian Supreme Court do not provide any guidance to properly distinguish reasonable chastisement from abuse.

The difficulty with direct reference to the de minimis principle is that it too 'appears to carve out a sphere of non- criminal conduct within the larger realm of common assault. ${ }^{73}$ However, it is not clear where these boundaries lie. Given that law enforcement agencies are to be involved in determining on a case-by-case basis which cases to prosecute as child abuse, and which not, the adducement of the de minimis principle opens the possibility of wide variation at the grass root level, and inconsistent policy developing. ${ }^{74}$

\section{The Positive Dimensions of Parental Physical Discipline?}

Inasmuch as the Court found a violation of child's right to bodily integrity by the continued existence of the reasonable chastisement defence, the Court nevertheless made what seem to be unusual and conflicting statements about the 'positive' dimensions of corporal punishment. For instance, the Court found that 'there might indeed be "sound and wisdom laden, faith based and cultural considerations behind the application of the rod". ${ }^{75}$ The Court further highlighted that intimate and loving parental chastisement is significantly different from the institutionalised administration of corporal punishment that has since been abolished. ${ }^{76}$ The Court hinted that properly managed reasonable and moderate chastisement could 'arguably yield positive results

69 Derived from the same common law heritage as South Africa's law, but subsequently statutorily enshrined in the Penal Code.

70 FORSA (n 1) para 25.

71 Ibid, para 40.

72 Durrant, Stewart-Tufescub, and Afifi (n 50).

73 J. Durrant, 'Slow and Not-So-Steady: Canada's Long Journey Toward Protecting Children from Corporal Punishment' in Saunders, Leviner, and Naylor (n 17).

74 As appears to have occurred in Germany: see M. Haug, 'The Years after the Ban - Dealing with Cases of Corporal Punishment by Parents in the German Criminal Justice System' in Saunders, Leviner, and Naylor (n 17).

75 FORSA (n 1) para 44.

76 Ibid, para 51. 
and accommodate love-inspired consequence management' that was averred by FORSA. ${ }^{77}$ The Court was further of the view that parents who truly chastise their children from love-driven religious or cultural bases 'only want the best for them'; ${ }^{78}$ and that it is debateable whether that form of discipline invariably produces negative consequences'. ${ }^{79}$ Further, the Court held that it would be an 'over -generalisation' to brand the very possibility of retaining the defence 'as an inescapable recipe for widespread excessive application of violence of child abuse'. This is indeed contradictory in the light of the clear prohibition on all forms of violence which the Court ultimately had to apply. ${ }^{80}$ The Court appears to give with the one hand, only to take away any advances with the other, hence the title of this article.

This nod to the supposedly positive aspects of parental corporal punishment is not necessarily going to appease supporters of corporal punishment, so it is not clear what purpose(s) these comments serve. It is suggested that they display excessive deference to parents who base their claims on entitlement to smack their children in culture, tradition, or religious reasons. However, it ends up playing into the very discourse of those who desire untrammelled parental freedom to exercise their parental responsibilities and rights as they wish, without state interference. Such doubleedged communication is likely to perplex many, include those tasked with further action, which is discussed next.

\section{THE WAY FORWARD}

The Constitutional Court ends the judgment by noting, ominously, that 'a proliferation of assault cases against parents is a reasonably foreseeable possibility'. This, the court said, law enforcement agencies should deal with on a case-by-case basis when cases of child abuse are reported. Both statements are disturbing, in that it is notorious that child abuse cases are poorly investigated and prosecutions are rather rare. ${ }^{81}$ This is particularly worrying given the levels of serious violence against South African children, and the poor follow up to reports of abuse and neglect up by both criminal justice and social welfare systems. ${ }^{82}$

Further, the Court clearly envisaged some or other regulatory framework to emerge from Parliament, sine the Court concludes that 'Parliament would hopefully allow itself to be guided by extensive consultations, research and debates before it finally pronounces on an appropriate regulatory framework. ${ }^{83}$ I submit that Parliament is going to be unclear of its role and remit given the complicating statement issued by the Court in FORSA.

77 Ibid, para 54.

78 Ibid, para 53.

79 Ibid.

80 Another backhander is to be found in para 64, where the Court found, in relation to studies on corporal punishment, that there is 'very little on truly moderate and reasonable chastisement' (emphasis added).

81 J. Sloth-Nielsen, 'South Africa's Child Protection System' in M. Skivenes and J. Duerr Berrick (eds.), The International Handbook on Child Protection Systems (Oxford University Press, New York, 2020, forthcoming).

82 Ibid.

83 FORSA (n 1) para 74. 
The Children's Act Amendment Bill was recently tabled at Cabinet (the version of February 2020), but it contains nothing related to corporal punishment. ${ }^{84}$ This is most surprising given the South Africa government's commitment to both the African Committee of Experts on the Rights and Welfare of the Child and the UN Committee on the Rights of the Child that it intends to outlaw corporal punishment through the medium of the Children's Act Amendment Bill. ${ }^{85}$

Just how any regulatory scheme would work is difficult to comprehend. Short of attempting to define a raft of de minimis exceptions in a fashion similar to the Canadian Supreme Court, the envisaged legislation can in reality do no more than abolish the reasonable chastisement defence ${ }^{86}$; whether Parliament would attach criminal sanctions for violations, or simply rely on the existing common law crimes of assault and assault with intent to do grievous bodily harm is hard to predict. That legislation might impose a duty on government to fund and support positive parenting discipline programmes is a possibility (and one that was foreshadowed by the 2002 South African Law Reform Commission).

\section{CONCLUSION}

As highlighted above, there are a number of inadequacies and strangely deferential statements in the FORSA decision. Whilst inescapably coming to the constitutionally correct decision, the reluctance of the Court to reach this point, and to accommodate the religious and cultural beliefs of the appellants, radiates. Why the Court felt it was not necessary to explore the full spectrum of constitutional rights at stake is not clear - can it be because the ultimate beneficiaries were mere children? Children's rights constitutional jurisprudence around the world is poorer for it. In the final analysis, the FORSA judgment has contributed little to South Africa's (international) standing as one of the leaders on children's rights in the world. ${ }^{87}$

84 A previous version of the Children's Act Amendment Bill that was gazetted on 28 October 2018 did contain provisions relating to corporal punishment; one of the amendments was the insertion of a new $12 \mathrm{~A}$ to the following effect:

(1) any person caring for a child, including a person who has parental responsibilities and rights $\mathrm{n}$ respect of a child, must not treat or punish the child in a cruel, inhuman or degrading way.

(2) any punishment within the home or other environment, in which physical force or action is used and intended to cause some degree of pain or harm to the child is unlawful.

(3) Any person who is reported for contravening subsection (1) must be dealt with in accordance with s 110 of the Act.

(Section 110 of the Children's Act triggers the social welfare investigation that may lead to the further involvement of the child protection system). As previously pointed out, this formulation was wanting in that it did not expressly abolish the defence of reasonable chastisement, not did it require reporting of unlawful physical conduct to the authorities. Further, it seemed to premise any contravention on the intent of the parent, so that a parent could legitimately defeat a charge under subsection 1 by arguing that the intent was not to cause the child pain or harm, but to discipline the child (J. Sloth-Nielsen, Conference Presentation, 22 Annual Miller du Toit Cloete/Unniversity of the Western Cape Conference, Cape Town, March 2019).

85 Sloth-Nielsen (n 64) 259. The Children's Act Amendment Bill, in preparation since 2013, contains a raft of amendments to many chapters of the Act.

86 See the recent legislative abolition of the reasonable chastisement defence in Wales on 20 March 2020 (Children (Abolition of Defence of Reasonable Punishment) (Wales) Act 2020).

87 See J. Sloth-Nielsen, 'Children's Constitutional Rights - A 20 year Retrospective' (2019) 52 De Jure 50120; see too A. Skelton, 'Too Much of a Good Thing? Best Interests of the Child in South African Jurisprudence' (2019) 52 De Jure 557-79. 